\title{
How Is Collective Identity Possible in Democracies? Political Integration and the Leitkultur Debate in Germany
}

\author{
Simon Bein (D)
}

Received: 9 July 2021 / Revised: 3 December 2021 / Accepted: 8 December 2021 / Published online: 11 January 2022

(C) The Author(s) 2021

\begin{abstract}
The quest for a common collective identity has become a challenge for modern democracy: Liberal demands for greater inclusion and individual freedom, aspirations for a strong and solidaric political community, as well as nationalist or right-wing populist calls for exclusion and a preservation of hegemonic national identities are creating tensions that cannot be overlooked. This article therefore formulates the central question of how collective identity can be possible in a liberal democracy. Based on a case study on Germany, it will therefore be examined whether Leitkultur as a model of political integration can serve in generating a functional democratic collective identity. The necessary benchmarks guiding the analysis will be defined beforehand from a systems-theoretical perspective, balancing inclusion and exclusion within three crucial dimensions: normative basics, historic continuity, and affirmative bindings. The results show that a static definition of a German Leitkultur would in the long run neither achieve functional inclusion nor be able to generate the necessary cohesion of a political community, especially regarding the second and third identity dimensions.
\end{abstract}

Keywords Integration $\cdot$ Political Culture $\cdot$ Identity Politics $\cdot$ Citizenship $\cdot$ Systems Theory

\footnotetext{
Simon Bein $(\bowtie)$

Institute of Political Science, University of Regensburg, Universitätsstraße 31, 93053 Regensburg, Germany

E-Mail: Simon.Bein@politik.uni-regensburg.de
} 


\section{Wie ist eine demokratische kollektive Identität möglich? Politische Integration und die Leitkultur-Debatte in Deutschland}

Zusammenfassung Die Suche nach einer gemeinsamen kollektiven Identität ist zu einer Herausforderung für die moderne Demokratie geworden: Liberale Forderungen nach mehr Inklusion und individueller Freiheit, das Streben nach einer starken und solidarischen politischen Gemeinschaft und nationalistische bzw. rechtspopulistische Forderungen nach Ausgrenzung und Bewahrung hegemonialer nationaler Identitäten erzeugen unübersehbare Spannungen. Der Beitrag formuliert daher die zentrale Frage, wie kollektive Identität in einer liberalen Demokratie möglich ist, hier verstanden als demokratische Identität. Anhand des Fallbeispiels Deutschland wird daher untersucht, ob Leitkultur als Modell politischer Integration eine funktionale Identität erzeugen kann. Der dafür notwendige Maßstab wird zuvor aus einer systemtheoretischen Perspektive definiert, die Inklusion und Exklusion in drei entscheidenden Dimensionen abwägt: normative Grundlagen, historische Kontinuität und affirmative Bindungen. Die Ergebnisse zeigen, dass eine statische Definition einer deutschen Leitkultur auf Dauer weder eine funktionale Inklusion erreichen noch den notwendigen Zusammenhalt eines politischen Gemeinwesens generieren kann, insbesondere im Hinblick auf die zweite und dritte Identitätsdimension.

Schlüsselwörter Integration · Politische Kultur · Identitätspolitik · Citizenship · Systemtheorie

\section{Introduction}

Liberal Western democracies have been experiencing difficulties in establishing a common identity: There are no longer static peoples, and the population structures are changing rapidly due to migration, globalization, and demographic shifts, which involves reconfiguring citizenship rights and related notions of shared identity. Then, within our modern political communities, many old cleavages between ethnics, nations, religions, and classes have broken down and new ones have emerged, posing anew the question of a sense of belonging together in times of identity politics (Fukuyama 2018b; Garcia 2018; Merkel and Zürn 2019; Mounk 2019).

To that extent, collective identity construction and maintenance can be identified as a central issue in the debate on the crisis of liberal democracy: "The final function of [...] identity is to make possible liberal democracy itself [...]; if citizens do not believe they are part of the same polity, the system will not function" (Fukuyama 2018a, p. 11). According to Fukuyama, the (collective) identity crisis of liberal societies is due to their typically postmodern exaltation of the individual. Similarly, Andreas Reckwitz (2017) has described these societies as societies of "singularities," and Marc Lilla (2016) criticizes liberal identity politics for promoting inequality and a loss of common sense, as well as political polarization.

Henceforth, the question of collective identity and integration is notably challenged by "the larger problem of the valuelessness of postmodernity. That is, the rise of relativism has made it impossible for postmodern people to assert positive 
values for which they stand, and therefore the kinds of shared beliefs they demand as a condition for citizenship" (Fukuyama 2006, p. 18). The central argument made here is that a common identity is necessary for the maintenance of a democratic political order. Ideals of integration and ideas of collective identity, it can be assumed, are closely linked together (Bizeul 2004; Fukuyama 2006; Koopmans et al. 2012; Pickel and Pickel 2018). From a systems-theoretical perspective, therefore, the question can be raised as to what such a functional model of collective identity can look like and which concrete concept of integration can fulfill these requirements.

The central thesis of this article argues that a functional model of political integration must, firstly, provide formal citizenship criteria that embody a liberal value foundation of the political community; secondly, be able to tell a narrative of commonality that is expressed in inclusive everyday cultural symbols and traditions; and thirdly, be the basis for a sufficiently strong affirmative commitment among members and toward the political order. Taken together, these assets form the three dimensions of a collective democratic identity, and, as I further argue, in each of these dimensions there appears a central conflict between a simultaneous need for inclusion and exclusion, or as Martin Sebaldt (2015, pp. 152-156) states, to avoid identity nihilism as well as rigid dogmatism. Therefore, since a strong one-sidedness in favor of one or the other can entail a "pathology of democracy" (Sebaldt 2015), a functional balance must be found between different conflicting requirements.

To demonstrate that, I will focus on German debates toward different models of political integration, especially the idea of a German Leitkultur. The German debate on political integration between an ethnocultural national identity, Leitkultur, and constitutional patriotism exemplifies these general "tensions between the particular and the universal, and between the specific and the general" (Isin and Wood 1999, p. 13) and thus represent the struggle of liberal democracies arguing for their common identity (Benhabib 1998; Jahn 2012). In general, it is necessary to distinguish between the ideological-philosophical debate on the respective concepts and their concrete implementation in political programmatic terms (Göhler 2003, p. 304): There is an academic debate on the idea of a German Leitkultur, which is embedded in the general question about social and cultural cohesion in modern, plural democracies (among others, Brubaker 2001; Manz 2004; Pautz 2005; Rohgalf 2016; Mouritsen et al. 2019; Ahrens 2021), a public debate on the topic (for instance, Lammert 2017; and Gauck 2017), and finally a political conflict between parties and their protagonists over implementing corresponding political measures that follow from these concepts (de Maizière 2017; Özoguz 2017; or Steinbrück 2018). In the following, an overview of the debate and its central arguments will serve as a starting point for approaching and evaluating the underlying programmatic concept of a Leitkultur.

The first part (section 2) contains the heuristic approach to a functional model of collective identity, building on the three identity dimensions and a systems-theoretical specification for the context of democracies. Then the second part (section 3) will analyze how far three types of political integration (national identity, constitutional patriotism, focus on Leitkultur) go to meet these requirements and enable a functional collective democratic identity. Finally, a conclusion (section 4) will be drawn 
with reference to the initial question, pointing to the need to constantly renegotiate and justify the foundations of democratic identity in all three dimensions.

\section{What is a Functional Democratic Collective Identity? A Systems- Theoretical Perspective}

Which are the values and principles a democratic collective identity can be based on in order to meet the requirements of a plural, open democracy, but at the same time to mark the demos as political sovereign in a meaningful way? It will, first of all, be necessary to define the term "identity" before looking at the relationship between functional requirements for a democratic collective identity and models of political integration.

In the context of this paper, identity shall mean collective identity within a democratic nation-state. This emphasizes the notion that we have to distinguish collective identity from social or personal identity concepts as well as from specific collective identities referring to particular group identities, e.g., religious, sexual, or regional (Straub 2018). In the following, I want to argue that three prerequisites must be met for collective identity to become virulent within a social group: a shared normative basis, a common idea about historic continuity, and a great deal of positive affirmation.

The normative groundwork contains common value and norm orientations, mostly retrieved from a transcendental, mythical, or ideological heritage (Vorländer 2013). For instance, in any religious collective, the basic religious precepts and values guidelines form the center of identity construction. Without these common normative convictions, a stable community is hardly possible in the long run, as Alexis de Tocqueville (1985, p. 219) stated in 1835 when analyzing the early American democracy. In this sense, Fukuyama's definition of identity as "one's true inner-self" (2018a, p. 6) can easily be transferred to the understanding of collective identity, namely in the sense of the collective's reason for demarcation toward the "other" and definition of the basic rules for any interaction on the inside.

But it is not only the pure values or norms that create binding ties; in addition, there comes along a specific idea of identity in time. That means that basic values and norms determining everyday life are incorporated in certain narratives, myths, or traditions and thus enable a common public memory (Anderson 2006; Hall 2018). This constitutes and justifies the basic normative groundwork, as, for example, French national identity is often traced back to the Revolution in 1789 and its ideas of freedom and equality. This second dimension, therefore, can also be seen as embedding the normative basis into a historical and cultural narrative that translates the core values and norms for its everyday reproduction. Of course, to avoid any essentialism, historical continuity cannot mean immutability; the need for adaptation and change should be emphasized here. In particular, democratic orders try to tie changes of their identity constructions to historical reference points, as the Australian example illustrates (Moran 2011).

Third, normative basis and historic continuity have to be completed by affirmative feelings. Max Weber (1964, p. 29) pointed out that in order to create a strong 
community, objective communalities are not sufficient. Instead, a subjective and emotional sense of belonging together is fundamental. But especially in diverse societies, conflicts between different levels of identification emerge and challenge strong affirmation toward the political system (Citrin and Sears 2009). Taken together, all three dimensions then result in collective identity as the "connective structure of a common knowledge and self-image, based on the attachment to common rules and values on the one hand, and on the memory of a jointly inhabited past on the other" (Assmann 2000, pp. 16-17). ${ }^{1}$

According to Talcott Parsons, every social system-as it is a political system-consists of the mutual relationships between four subsystems and their main functions: integration, pattern maintenance, goal attainment, and adaptation (Parsons 2003, p. 20). In Parsons's description of social system maintenance, the relevance of what has been described here as democratic identity becomes clear: To some extent, there must be a consensus among members of the system regarding a common value base that allows these value orientations to be institutionalized and symbolized, thus creating loyalty and solidarity (Parsons 2003, 26). Without the latter, it is questionable what "morality," as Parsons calls it, should commit the various actors to each other in their actions within the system. To enumerate this necessity of a common identity, Fukuyama (2018a, p. 10), for example, emphasizes three possible consequences of weak identities, pointing to the system-theoretical connection between collective identity and the political system: insecurity due to state-collapse processes or separatist aspirations; diminished quality of government caused by corruption and ineffective public services; or negative effects on economic developments, originating in a lack of willingness to perform or individual advantage-taking instead of solidarity-based orientation toward the common good.

It becomes clear that the construction of collective identity and democracy are closely connected (Benhabib 1998; Habermas 1993; Kymlicka 1995; Taylor 2002). A modern, plural, and democratic society will inevitably be a society of multiple identities. Our focus here lies on what I call democratic identity (Bein 2020a). This concept of identity considers the members of the society within a democratic nation-state, correspondingly the owners of full citizenship rights, as the collective of reference, and it therein focuses on values, norms, and shared attitudes on an aggregated political level. The question of how to construct and legitimate binding ties within a community of free and equal men and women determines political and philosophical thinking about democracy from the beginning because the absence of any idea of belonging makes it hard to implement democracy in the sense of a sovereign, self-governing people (Taylor 2002). Democratic collective identity insists on the demos as its constituent social group within a democratic political system. How deep can democratic identity reach without being too exclusive and thus violating the values of democratic universalism? And how, on the other side, can democracy prevent excessive inclusion that weakens connections between members and identification with the political community? Inclusion in this sense refers not just to the integration of migrants and asylum-seekers; instead, the term is understood in a sociological, system-theoretical way and means the integration of different social

\footnotetext{
1 Translated by the author.
} 
groups and systemic parts into the political decision-making process, based on the understanding of free and equal participation rights (Young 2000

As not only Landwehr and Steiner (2017, p. 788) have pointed out, "citizens even and particularly in pluralist and consolidated democracies have differing normative conceptions of democracy from which different democratic aspirations follow." Therefore, we can suggest that apart from a liberal, procedural consensus on the core principles of democracy, there exist various "conceptions of democracy on which citizens can legitimately disagree" (Landwehr and Steiner 2017, p. 790). Antipluralist attitudes and identity narratives based on the idea of a certain cultural homogeneity result in a more closed conception of democracy. This becomes visible in opinions on immigration, cultural pluralism, and inclusive citizenship rights (Bergem 2019; Siri and Lewandowsky 2019). In addition, some emphasize the exclusive element of a democratic political order while arguing that not only the consensus on procedural elements of decision-making and negotiating of different interests in a pluralist market situation by the highest possible participation of all individuals result in a functioning democracy, but also that certain prepolitical requirements for participation within the democratic process are necessary. Sure, the universalism of democratic values such as human dignity and other fundamental rights is always contradictive with the need to constitute a concrete subject that governs, which is why exclusion will always be a part of democracy (Taylor 2002, p. 30).

Thus, if one wants to establish a functional democratic identity-Oliver Hidalgo (2020, p. 21) refers to this simply as the identity of democracy-one must first establish that legitimate but conflicting tensions exist between left-wing and rightwing identity politics, which place different demands on inclusion and exclusion, plurality, and preservation of homogeneity. Democracy must preserve this diversity of legitimate positions, especially on issues of political integration, and translate it into a political dispute. "The 'identity' of democracy itself is thus only preserved if both left-wing and right-wing identity politics register at best partial successes, stage victories and/or temporary gains. The contradiction itself, the opposing political identities, which in different ways emphasize the 'same' and 'unequal' that exist in parallel in democracy, must remain intact" (Hidalgo 2020, p. 22). ${ }^{2}$

A functional model of collective democratic identity must therefore first be developed against the background of a core liberal-procedural concept of democracy in order not to anticipate a priori certain normative and ultimate justifications for a certain model of democracy and its identity. Henceforth, nihilism on one side and dogmatism on the other side are main sources toward a dysfunctional, pathological way of identity maintenance (or loss). Dogmatic adherence to a uniform identity, which does not permit deviations and adjustments, can have just as destabilizing an effect on the system as the nihilistic rejection of any consensus on values (Sebaldt 2015, pp. 48-49) (Table 1).

An approximation to a functional model of democratic identity can thus look as follows: Ideally, democracy provides an inclusive identity offer to which a large proportion of citizens feel connected and which, in addition to providing a common normative basis, can also create an emotional, solidarity-based connection between

\footnotetext{
2 Translated by the author.
} 
Table 1 Democratic collective identity dimensions and their functional expression

\begin{tabular}{ll}
\hline Identity dimension & Functional expression \\
\hline Normative basics & $\begin{array}{l}\text { General values and norms provide orientation and guarantee integration of } \\
\text { social groups based on a liberal constitution }\end{array}$ \\
Historic continuity & $\begin{array}{l}\text { Narratives of collective permanence lay the groundwork for cultural habits and } \\
\text { everyday traditions but remain open for transformation } \\
\text { Affirmative bindings }\end{array}$ \\
$\begin{array}{l}\text { Mutual feelings of solidarity and collective belonging ensure the cohesion of } \\
\text { the political community }\end{array}$ \\
\hline
\end{tabular}

Own illustration

members of a society (see Table 1). But this offer must also be open to joint negotiation and dynamic adaptation to new circumstances, a changing population, and newly arriving population groups who can participate equally in the process of identity formation. Martin Sebaldt summarizes this functional approach to the problem of identity in democracies as "consensual identity formation": "[T]he search for ethically binding values is not dogmatically authoritarian but takes place in a broadly based and inclusive process, which is in principle initially open to all value offerings" (Sebaldt 2015, p. 189). The further delimitation of this functional democratic identity configuration in normative terms is difficult, however, and must be carried out empirically and inductively. For this purpose, the examination of the present integration concepts is central by analyzing whether there are approximations to the dysfunctional poles and whether exaggeratedly inclusive or exclusive components can have a disintegrating effect on democracy.

\section{The Case of the German Leitkultur}

\subsection{Political Integration in Germany Between Ethnocultural National Identity and Constitutional Patriotism}

This paper aims to consider whether Leitkultur as a model of political integration has the potential to create a functional democratic collective identity. For this reason, I have defined a type of collective identity within democracies that balances the need for inclusion and integration on one side and the clear but open demarcation of the political demos on the other side.

As Gerhard Göhler (2003, p. 305) points out in an important theoretical consideration on the Leitkultur concept, the latter can be situated between two poles of political integration: national identity as the affective identification with a hegemonial national culture and its passed-on values or traditions on one side, and constitutional patriotism as collective identification with political principles and ideas of the constitution on the other.

Until today, the nation-state as object of identification and emerging collective identities has resembled the dominant framework for political systems. Thus, on the one hand, national identity represents the constructive connection between the identity-building myth of a nation and the concrete borders of a political entity (Eisenstadt 1991), mostly at least since Riedel (2018) points to the potential for 
conflict between national identities beyond state borders through separatist aspirations. On the other hand, Smith (2000) clearly shows that the narrative of a national identity becomes evident only by activating further, primordial resources, which are first and foremost of cultural, ethnic, or religious origin. Most prominently, Ernest Gellner (1983, p. 55) argued that only ethnocultural units can produce a strong and stable national identity and that processes of adaptation are essential in multinational or multicultural states.

Stuart Hall (1994, 2018) developed an influential concept of national culture that illustrates exclusive tendencies for identity formation coming along with that idea of national identity: According to Hall, in times of loss of formerly stable affiliations through race, class, or gender and the ensuing identity crisis of subjects, national identity emerges primarily through the structural exercise of cultural power. Consequently, national cultures represent a central source of collective identity: The cultural system of meaning thereby produces the understanding of what is to be understood by national belonging (also Anderson 2006).

The nation is then conceived as a "symbolic community" (Hall 1994, p. 200), to which regional and ethnic identities have increasingly been subordinated in modernity.

Hall thus conceives national culture primarily as a representational system: "National cultures construct identities by producing meanings of nation with which we can identify" (1994, p. 201). Referring to Hall, the resulting narrative of national identity contains, in principle, the following five elements: first, the periodic, temporally persistent visualization of the nation in stories, literature, media, and everyday customs; second, the reference to the natural givenness of the nation, to which a static core is attributed despite all historical ruptures; third, the inculcation of national-typical values and behaviors, especially via internalization of traditional patterns of behavior; fourth, the concrete reference to a founding myth, a birth of the nation; and fifth, behind all this is the idea of the purity and originality of the people (Hall 1994, p. 202).

As a consequence, citizenship, as full and legal membership in the political community and its related duties and rights, is primarily connected to the idea of a nation. Isin and Turner even state a "nationalization of citizenship" (2007, p. 12) because universal principles of democratic citizenship contrast with the more exclusive and limited integration models of particular collective identities (ethnicity, race, nation, religion, etc.).

The integration model of national identity, as Göhler (2003, p. 310) designs it, thus does not seem suitable in several respects, and regarding all three dimensions to favor a functional model of democratic identity: the normative basis remains vague and makes an inclusive reference to seem unlikely in times of no longer clearly identifiable peoples and their majority cultures. Whereas national identity as a special form of collective identity refers to imaginations of the nation, a functional democratic identity insists on the demos as the constituent social group within a democratic political system (Francis 1965). Thus, the presented model of integration based on an ethnoculturalist understanding of national identity reveals exclusive elements of identity construction in the realm of historical continuity and affirmative ties. Mouritsen even points out that despite the formal shift away from the integration 
concept of national identity toward liberal-universal political values, it can often be seen that "national citizenship policies still reflect continuities, and path-dependent reactions to such continuities, of culturally bounded nation states" (Mouritsen 2013, p. 86; see also Brubaker 2001). Göhler (2003, p. 307), though, emphasizes for the German case that this type of national identity can no longer represent a functional pattern of integration, since the breaks in historical continuity are too great. ${ }^{3}$

The other pole of political integration is marked by the liberal idea of constitutional patriotism. Hence, Cronin calls it the answer to "chauvinistic particularism of traditional forms of nationalism" (2003, p. 20), which, however, for the time being cannot do without the surrounding framework of democratic nation-states and their constitutions. Originally, it was introduced in the 1970s by Dolf Sternberger, who aimed to find a legitimate way to create an afterwar German identity and a new nonnationalistic patriotism without the heritage of an ethnically based people (Volk) (Sternberger 1990). Later on, the German philosopher Jürgen Habermas gave further development to the term (Habermas 1994).

Generally speaking, constitutional patriotism implies "a form of attachment to norms, values and procedures that are contained (or at least suggested) in a liberal democratic constitution" (Müller 2007, p. 380). It offers a term that "not necessarily suggests a strict homogeneity of beliefs or political dispositions. It can also be characterized by persistent and characteristic forms of public disagreement" (2007, p. 380). As a matter of fact, the idea of a constitutional patriotism surely contains elements that have also been considered in the understanding of a European Leitkultur, as will be described later on (Stein 2008, p. 50). But it is at the same time important to recognize that exponents of this approach specifically intend not to create cultural preconditions for political integration. Habermas worked this out with great importance, searching for legitimate sources of unity and collective identity in a modern and diverse society: Democracy can, regarding to Habermas (2006), reproduce itself without referring to specific cultural or religious sources by focusing on the rationality of the democratic process and its constitutional freedoms and rights (see also Rawls 2003).

The former Federal President Joachim Gauck referred to this concept in his farewell speech in January 2017 and intended to disprove "all those who regard constitutional patriotism as a weak, bloodless construct" (2017, p. 6). For Gauck, constitutional patriotism is identification with the political ideal of democracy, the possibility of self-empowerment of a political community under the ideals of freedom and equality. In this context, democracy is above all a space of political dispute that takes place between different lifestyles, everyday cultures, and opinion groups, all of which, however, feel bound to the principles of the Grundgesetz (Gauck 2017).

Finally, the differentiation of the three dimensions of collective identity helps us to understand why constitutional patriotism will not be able to create a functional collective democratic identity either. Constitutional patriotism can indeed rely on a reasoned explanation of unifying political values and thus does not need any reference to exclusive and culturally transmitted patterns of identification. It marks the

\footnotetext{
${ }^{3}$ For further elaboration on the ethnocultural conception of a German national identity and its critique, see Fulbrook (1999) and Wittlinger (2010).
} 
intention to create a political, nonethnic, and less culturalist model for integration and identification and primarily is based on values and norms of liberal democracy and its constitutional guarantees (Cronin 2003). Constitutional patriotism initially gets by without committing to a specific historical continuity, theoretically even without establishing reference to a specific territory (although the need for the same language is acknowledged), and in principle also does not presuppose strong affirmative feelings such as solidarity among its members (Müller 2010, p. 63). But, according to Müller, the crucial point is that it can generate all this without nationalist or culturalist instrumentalization. Likewise, Cronin considers constitutional patriotism to be a functional collective identity for modern democracies and a "viable alternative form of political identification to chauvinistic nationalism" that is "capable of commanding allegiance while nevertheless remaining open to transformation" (Cronin 2003, p. 2).

How this is to be achieved in concrete terms, however, remains more than indeterminate. Thereupon, I argue that not only the concept of national identity shown above but also this sort of constitutional patriotism can hardly fulfill the functional requirements of democratic collective identity. On the one hand, this makes the concept of constitutional patriotism very inclusive in the normative field: In the spirit of liberalism, everyone should identify with the political values of the liberal constitution, since this makes it possible to lead a self-determined and "good" life (Göhler 2003, p. 309; see also Oberndörfer 2001). On the other hand, this normative inclusivity cannot explain why strong and solidary affirmative bindings develop between members at the emotional level, as not only Göhler (2003, p. 310) has pointed out.

The reason is a specificity of the second dimension of collective identities that translates normative values and principles in symbolic interpretations of historical continuity: Access to this symbolic interpretive power remains exclusive and unequal, and thus dependent on cultural embeddings of the formal-universal principles. "This is not only about the rational justification of one's orientation, but also about passion [...], and thus precisely also about rational vagueness" (Göhler 2003 , p. 309), whereby this diversity of possible interpretations can have a centrifugal and, depending on the majority, exclusive effect. Exclusion, in turn, can be generated by the majority constructing and defaming "supposed enemies of the constitution" (Müller 2010, p. 78) in the name of absolute constitutional loyalty, especially when immediate confessions are demanded from newcomers (Müller 2010, p. 79).

Göhler (2003, p. 305) argues that the concept of a German Leitkultur is characterized as a political integration pattern in between the identification with political and normative values of the constitution and the cultural-based identification with a nation. In this sense, Göhler claims that the concept of Leitkultur "can serve an important political function: an orientation of citizens towards the polity that lies between constitutional patriotism on the one hand and national identity on the other-more than just an internalized obedience to the constitution and laws, less than a purely affective identification with a (national) polity" (2003, pp. 305-306). In the following, I would like to show why this is not the case and why the Leitkultur concept cannot generate a functional democratic identity either (see Table 2). 
Table 2 Models of political integration and their collective identity dimensions

\begin{tabular}{llll}
\hline & Normative basics & Historic continuity & Affirmative bindings \\
\hline $\begin{array}{l}\text { Constitutional } \\
\text { patriotism }\end{array}$ & $\begin{array}{l}\text { Open: liberal constitution, not bound } \\
\text { to a particular culture }\end{array}$ & $\begin{array}{l}\text { Open and rather } \\
\text { weak, as based on } \\
\text { universal values }\end{array}$ & $\begin{array}{l}\text { Low-based, rational } \\
\text { identification with } \\
\text { normative rules }\end{array}$ \\
& $\begin{array}{l}\text { De jure open: liberal constitution } \\
\text { embedded in a certain cultural her- }\end{array}$ & $\begin{array}{l}\text { Strong and fixed, } \\
\text { acculturation is } \\
\text { itage (de facto rather closed) }\end{array}$ & $\begin{array}{l}\text { High requirements, } \\
\text { possible by assimila- } \\
\text { tion }\end{array}$ \\
$\begin{array}{l}\text { National } \\
\text { identity }\end{array}$ & $\begin{array}{l}\text { Closed: ethnocultural heritage of } \\
\text { a nation }\end{array}$ & $\begin{array}{l}\text { Strong and fixed, if } \\
\text { any, acculturation is } \\
\text { expected }\end{array}$ & $\begin{array}{l}\text { High requirements, } \\
\text { if any, possible by } \\
\text { assimilation }\end{array}$ \\
\hline
\end{tabular}

Source: Own illustration based on Göhler (2003, p. 310) and Ohlert (2015, p. 33)

\subsection{The Leitkultur Debate and its Main Arguments}

The first impulse for the political debate on the concept came from the German professor of Syrian origin Bassam Tibi (2001; 2018). He understood Leitkultur as a "strategy of peace presented by an immigrant [...]" (Tibi 2002, p. XVI) ${ }^{4}$. It was Tibi's intention to define a European Leitkultur and thus to emphasize Germany's identity as inseparably connected with the history of Europe, the Enlightenment, and the secular modernization process. This approach of creating a liberal idea of a common European culture, which simplifies integration for migrants because of clear cultural requirements, is deeply driven by the fear of societal disintegration and parallel cultures (Manz 2004, p. 484). It was Tibi's crucial argument that without a common identity and the consciousness about a common cultural heritage, Germany and all European societies would run into danger of falling apart and could not succeed in overcoming the challenges caused by increasing immigration (Tibi 2002, p. 57).

According to Tibi, the core elements of a European Leitkultur for Germany are thus "the primacy of reason over any religion"; individual human rights, especially freedom of belief; a separation of religion and politics; democracy; pluralism; and "mutually valid tolerance" (Tibi 2002, p. 56). In light of this Leitkultur understanding, it becomes clear that it is especially important to realize Tibi's idea of culture: As he makes clear, it is not in his interest to deny cultural pluralism but rather "identity-less multiculturalism" (Tibi 2002, p. 49). In this sense, Europe should not be seen as a mere residential area for different cultural-communitarian groups, as he calls it, but instead should demonstrate its cultural richness under the common umbrella of crucial binding values. The main source for this overarching identity should be European cultural modernity (Tibi 2002, p. 50).

Finally, it is not easy to classify Tibi's Leitkultur approach. Stefan Manz (2004, p. 484) summarizes it as "based on universalist republican and civilian values that have developed in the wake of the European enlightenment and the bourgeois revolutions." But surely, to this interpretation we have to add Tibi's focus on a specific idea of national culture that embeds a universalistic, enlightened idea of a European civilization within national specifics. One reason for this possible culturalist inter-

\footnotetext{
4 Translated by the author.
} 
pretation in Tibi's universalism could be that, as Mouritsen (2013, p. 100) points out, civic republican concepts of integration in Germany focus less on the explicitly political level and instead address the cultural realm, as, for example, through integration via sports or churches.

In the following years, consequently, the connotation of the term changed. From a liberal, European-embedded idea of a cultural civilization, the early 2000s brought the term away from Tibi's initial intent toward a more exclusionist definition of a particular German, and not European, Leitkultur (Merz 2000; Häusler 2002; Hentges 2002). In 2017, Tibi criticizes the evolution of the debate he initiated, especially the change of connotation toward an ethnical, or at least culturalist understanding of majoritarian hegemony: "The Leitkultur should be a motor of growing together, with which everyone could find his place, so that everyone would be better off. I understand Leitkultur as a universalistic, non-ethnic concept of citizenship, which just opens the national identity for newcomers" (Tibi 2017). ${ }^{5}$ But according to Pautz, in Tibi's argumentation, especially with regard to his call for overcoming German identity damages caused by the Holocaust and his labeling of the Islamic cultural sphere as incompatible with democracy, Pautz (2005, p. 77, 108) sees elements of rightist argumentation patterns that may have at least contributed to the further interpretation of the term.

The appeal for a Leitkultur as a consensus of values (Tibi 2002) can be understood as a clear criticism of a destabilizing, disintegrating overemphasis on inclusion within multiculturalism. The absence of a certain degree of cultural integration prevents, from this point of view, the agreement on a universal value basis. Nevertheless, it is unclear how Tibi intends to maintain the universalism of values he demands without a specific culturalist interpretation, which he himself has given by referring to German history as the heartland of the European Enlightenment. In this respect, different interpretations of inclusion and exclusion are close to each other and have prepared the way for the continuing debate.

The rapidly increasing number of asylum seekers and refugees from 2015 onward, particularly from the civil war-torn country of Syria, again accelerated the debate and revealed the need for Germany to "rethink its own collective identity and clarify what is an elementary and indispensable part of it" (Münkler and Münkler 2016, p. 11). ${ }^{6}$ The electoral successes of the Alternative for Germany party (AfD) and the continental strengthening of "authoritarian national radicalism" (Heitmeyer 2018), whose actors such as the Identitarian movement or the right-wing faction of the European Parliament Identity and Democracy already bear the concept of identity in their names, have also made their contribution.

The then-president of the German Bundestag and CDU politician Norbert Lammert in 2017 sharply criticized the idea of integration through constitutional patriotism as insufficient: "The correct reference to the norms and values codified in the Grundgesetz and its validity for all people living in Germany is not enough on its own. Constitutions do not fall from the sky, but presuppose values that have grown historically and culturally, which they concretize in legal forms" (Lammert

\footnotetext{
5 Translated by the author.

6 Translated by the author.
} 
2017). ${ }^{7}$ In the same year, the then-German Minister of the Interior, Thomas de Maizière $(\mathrm{CDU})$, generated headlines for a broader public by trying to define German Leitkultur in a populist, close-to-the-people way (de Maizière 2017). First, de Maizière refers to the basic constitutional consensus that must be respected by everyone: "We respect the fundamental rights and the Grundgesetz. The human dignity is inviolable. We are a democratic constitutional state. We speak the same language, our common language is German. For all that we have a word: Constitutional Patriotism. A good word" (de Maizière 2017). ${ }^{8}$

Furthermore, de Maizière argues that these binding elements on a political, constitutional level are not enough and that there is the additional need for a common Leitkultur. Basically, he wants the term to be understood as a "guideline" in the sense of "unwritten rules of our living together" (de Maizière 2017), ${ }^{9}$ for example, saying one's own name and shaking hands for welcoming. But the former German Minister and high-ranking CDU politician goes further and exemplifies his ideas in a more detailed manner: A Leitkultur for Germany values individual performance, in education, sports etc., and gives help and solidarity to those who need it. A Leitkultur for Germany, according to de Maizière, appreciates cultural achievements, not only Bach and Goethe, but also within daily life, being proud of theaters, concert halls, and other cultural elements. Religion plays an interesting role, too: "Germany is characterized by a special state-church relationship. Our state is ideologically neutral but friendly to the churches and religious communities. Church holidays shape the rhythm of our years. Church towers outline our landscape" (de Maizière 2017). ${ }^{10}$ Similar to the official note within the party government program, de Maizière emphasizes the value of European integration and Germany's place in the middle of Europe and the Western alliance, and he highlights the value of local and regional customs and traditions as well as the need for an enlightened patriotism, combined with tolerance and respect for minorities.

The renewed topicality of the issue since 2015 has led to positioning and demarcation attempts, especially among the parties of the center, to address the moods in the population and the enormous increase in importance of the issues of identity and migration. Above all, the articulation of a sense of threat to Germany's cultural identity, by Islam in general and by refugees and immigrants in particular, has become a central political issue for right-wing political actors (Heitmeyer 2018).

The associated public debate in Germany continues today. ${ }^{11}$ Namely, the young German representative and CDU member Philipp Amthor recently postulated a renewal of the Leitkultur debate after it was originally introduced about more than 20 years ago. Amthor's contribution is particularly interesting with regard to that part

\footnotetext{
7 Translated by the author.

8 Translated by the author.

9 Translated by the author.

10 Translated by the author.

11 The Leitkultur debate, as it has unfolded since Bassam Tibi introduced the term in the late 1990s, cannot be fully traced here. For this purpose, although mostly in German, Piwoni (2012), Ohlert (2015), and Meier-Walser (2017), or in English, Manz (2004) and Pautz (2005). In European comparison, Mouritsen et al. (2019) are worth mentioning.
} 
of the debate, which criticizes the idea of a Leitkultur as cultural hegemonic and instead emphasizes the binding forces of the German constitution, the Grundgesetz. (Basic Law), and its political values. Amthor states that this sort of constitutional patriotism cannot substitute for discussion about common cultural roots that hold the society together: "The Grundgesetz is not the limiting end of a Leitkultur debate, but rather its starting point. It is one of the biggest strengths of our Grundgesetz that it is permeated by the spirit of our culture and tradition" (Amthor 2020, p. 20). In this statement, one can identify the general struggle between conflicting principles of democracy: Does a political community within a democratic system necessarily need common cultural roots, or can political, universal values create identification with the democratic state and constitute the basis for a shared identity? The debate on a common German Leitkultur symbolizes this conflict and therefore can be read as a debate about German collective identity itself (Bein 2020b).

But the debate about the need for (or rejection of) a Leitkultur as the basis for integration and social cohesion has only belatedly given rise to something like a political concept, which in the following is the object of further analysis. The transition from central arguments of the Leitkultur debate to the examination of concrete political implications of the concept highlights the dysfunctional contradiction between normative foundations meant to be inclusive and the opportunity for mutual, equal affective identification, which has an exclusive effect due to the power of interpretation remaining with the majority.

\subsection{Leitkultur as a Functional Model of Democratic Collective Identity?}

Can the Leitkultur idea pacify the German debate about a common identity between ethnocultural nationalism and liberal constitutional patriotism and provide a functional synthesis between these two poles?

As stated by Mouritsen et al. (2019, p. 645), Leitkultur debates pursue two objects, one of manifest and one of latent character: As a manifest function, the Leitkultur idea intends to offer simplified integration of immigrants through clear verbalization of requirements for societal acceptance and acculturation, whereas the latent function is more focused on the overall societal context by increasing trust and bonds within society. According to the authors, Leitkultur fails both functions, foremost with regard to its concrete policy implications: "To this end, however, the policy relevance of Leitkultur is dubious, because its manifest functions miss their mark and provoke, and because the latent enhancing of trust is unlikely. [...] It is an unfortunate characteristic of common values debates that a too insensitive, stigmatising pursuit of the former (manifest) functions are likely to hurt the latter (latent), at least on the side of newcomers' trust and identification" (Mouritsen et al. 2019, p. 648).

The manifest function described here concerns first and foremost the normative dimension of collective identity: Leitkultur is intended to define central values that are the basis for integration and cohesion in society and thus provide clear orientation for newcomers. In the Leitkultur concept, too, these normative foundations are initially inclusive, similar to constitutional patriotism, and refer primarily to values of political liberalism and Western democracy (Mouritsen et al. 2019, p. 645). But two problems arise in the area of normative basics that complicate a functional 
identity construction. Contrary to Göhler's assumption that the Leitkultur concept would be suitable for filling the voids of constitutional patriotism and national identity while at the same time remedying their weaknesses, the formally definable and consensual normative canon of values also remains too vague in the case of Leitkultur. "Discourse on common values is probably ineffectual as a means of integration, often unfocussed, and thereby harmful” (Mouritsen et al. 2019, p. 645). Hence, beyond the formally inclusive normative foundation, a return to national-cultural foundations and specifically Western interpretations emerges, which in turn symbolizes a "deeply hegemonic claim, by singling out one particular form of culture over all others" (Palmowski 2008, p. 557). Mouritsen et al. distinguish these "double standards" (2019, p. 646), particularly regarding the implementation of universal normative foundations, which then tend to be exclusionary toward certain groups. Other authors also confirm this duplicity of some Leitkultur aspects, for example when the value of tolerance is emphasized but group-based distrust and antipluralistic attitudes are widespread, as empirical studies have shown (Heitmeyer 2018, p. 332).

This was particularly evident in the Bavarian state government's attempt to legally anchor Leitkultur as an integration obligation in its own integration law (Bayerischer Verfassungsgerichtshof 2019). ${ }^{12}$ The state parliamentary groups of the Social Democratic Party of Germany (SPD) and Alliance 90/The Greens (Die GRÜNEN) filed a constitutional complaint against the Bavarian Integration Act (BayIntG), which took effect in January 2017. This complaint was partially confirmed by the court and some elements of the Bavarian Integration Act were thus declared unconstitutional. The law passed by the governing majority of the Christian Social Union (CSU) contains, among other things, the concept Leitkultur in the preamble, which defines as "identity-forming basic consensus" and "basic cultural order of society" many of the political elements already mentioned (among others, human dignity, freedom and equality, rule of law) (Bayerische Staatskanzlei 2016; Heinhold 2018). But not only that, as part of the Leitkultur, the preamble also contains Bavarian customs and traditions as well as the anchoring in the Christian Occident, which precisely symbolizes the balancing act between political inclusivity and de facto exclusion through cultural interpretive power. Building on this, the law sets a series of integration goals (Art. 1 BayIntG) and requires immigrants in Bavaria to respect this Leitkultur

The parts of this law that were declared unconstitutional show how difficult it is to implement Leitkultur as a model of integration beyond vague political-universal normativity (Bayerischer Verfassungsgerichtshof 2019, p. 4): First, a legal obligation for print and telecommunications broadcasters to convey the defined Leitkultur elements (Art. 11 BayIntG) is not compatible with freedom of the press and freedom of expression as fundamental rights. Second, requiring persons to attend a course on values of the free democratic basic order at the inducement of security authorities (Art. 13 BayIntG) is also a violation of freedom of expression. However, not all the criticism of the opposition groups was upheld. The court ruled that it is indeed lawful to set such integration goals for the Bavarian state and, as an example,

\footnotetext{
12 For this valuable advice, I thank the anonymous reviewers of the PVS.
} 
Christian occidental culture can be preserved by law in early childhood education (Bayerischer Verfassungsgerichtshof 2019, p. 9).

The imbalance between inclusion and exclusion is, thus, clearly evident in the second identity dimension, historical continuity: While in the normative realm a functional mixture of political-universal values and everyday cultural integration could indeed be established, as Göhler (2003, p. 310) recognizes, the de facto exclusive continuity of a specific national-cultural narrative becomes apparent here. Heinhold (2018, p. 210) puts it even more drastically, judging this law to be a very dark moment of Bavarian parliamentary legislation, as the attempted demarcation to the Right and selfish campaign tactics led to the political instrumentalization of a "reactionary image of society" that would violate elementary democratic and constitutional principles. In addition, Heinhold demonstrates in great detail the attempt of this Bavarian Integration Law and its Leitkultur conception to prescribe a majority culture and the associated hegemonic narrative in a static way: Being deeply rooted in Christian occidental culture can no longer apply to the vast majority of the population in view of empty churches, a lack of priests, and sometimes little everyday respect for numerous Christian commandments (2018, p. 200); even the shaping of city and countryside by Bavarian customs is not a characteristic for eternity in times of fast food and the growing death of classic local taverns (2018, p. 197). Rather, the attempt to legally establish Leitkultur here must be declared as an attempt to maintain exclusive sovereignty over the concept of homeland, or Heimat (Ahrens 2021).

Exclusive elements coming along with some parts of the historical narrative of Leitkultur can be traced back to Germany's redemocratization after the Second World War and the return of 12 million expellees from Eastern Europe back into Germany, who were seen as an ethnic part of a natural people (Hess and Green 2016, p. 317). The "concept of a Volk tied together by ius sanguinis or blood descent" (Pautz 2005, p. 40) dominated the discussion on immigration, integration, and citizenship for a long time. As Schönwälder and Triadafilopoulos add, few changes that occurred in the meantime, as, for example, the introduction of voting rights for European Union-foreigners on the local level, can be interpreted as a pragmatic answer "to an exclusionary citizenship policy at the national level and to a (perceived) unwillingness among guest workers to become German nationals" (2016, p. 369). Therefore, integration policy and the corresponding idea of collective identity in Germany for a long time can be described as exclusionist and ethnic-based, due to ethnos and demos resembling each other.

In line with the general shift in the understanding of race, nation, and ethnicity, as Stuart Hall (2018) calls the "fateful triangle," the shift in significance away from race or ethnicity to what is actually understood by culture can then be observed. The construction of historical continuity becomes the central object of collective identity formation since the normative core values of liberal democracies are considered universal and nonnegotiable. Historical continuity inherent to the Leitkultur concept can be seen in the one-sided promotion of cultural values, as Martin Ohlert (2015, pp. 250-252) shows: Requirements for obtaining citizenship should be significantly expanded, according to demands made by the CDU/CSU in the context of the Leitkultur debate, especially regarding the Christian heritage and reservations 
about the compatibility of Islam and the day-to-day culture of Western societies. A connection to historical continuities and cultures of immigrants is not politically promoted, and in some cases is even attempted to be prevented, which corresponds to a clearly exclusive and, in the long run, rigid and dysfunctional arrangement of this identity dimension. Although it is obvious, with the normative charge of historical-cultural practice and everyday culture apparent here, that the original identity dimensions of normative basis and historical continuity are difficult to separate.

This provides the direct transition to the affirmative dimension of collective identity. Can Leitkultur make a functional democratic identity possible here? That is doubtful, just as in the case of a purely liberal, multicultural, and therefore inevitably weak identity formation. As Leitkultur has been defined, for example, in the aforementioned Bavarian Integration Act, it functions as a one-sided enumeration of integration obligations and fixed endpoints of cultural assimilation. In this respect, one can agree with the judgment of Mouritsen et al. (2019, p. 648) that a functional contribution of the Leitkultur concept to a mutual strengthening of trust and increasing social cohesion is not to be expected (see also Heitmeyer 2018, p. 333). A functional democratic identity must be open and adaptable in its construction process and allow for the participation of new and relevant groups. This corresponds to the latent function of Leitkultur to preserve cohesion and trust within society through assimilation (Mouritsen et al. 2019, p. 647). It is clear that despite the shift away from ethnic-based understandings of national identity, a strong focus on the cultural community persists. Leitkultur as a civil, universally accessible model of integration, as formally established in the normative sphere, cannot work, because "some civic values arise within a majority history and may only be appreciated as such" (Mouritsen et al. 2019, p. 644). Furthermore, the importance of recognition for identity conflicts has been clearly elaborated not least by Francis Fukuyama: Without recognition, the expectation of adaptation and integration leads to mutual affective bonds that can sustain a democratic community only with difficulty: "Identity grows, in the first place, out of a distinction between one's true inner self and an outer world of social rules and norms that does not adequately recognize that inner self's worth or dignity" (Fukuyama 2018b, pp. 9-10).

To prevent these conflicts, a process of mutual understanding must take place that also strengthens the affirmative bonds. That this will be difficult under the catchphrase Leitkultur is also shown by the fact, for instance, that it does not appear at all in the National Action Plan on Integration (NAP-I) by the Federal Government (Bundesregierung 2020), although it was included in the last government program of the conservative Union parties, and, as already seen, the Bavarian CSU has even 
created a legal basis for it. ${ }^{13}$ The NAP-I aims to systematically design measures for successful integration in five phases and numerous thematic forums together with all the important players in this policy field. In Phase IV (Growing Together), the section on culture states, "The identity-forming and integrative power, the creative, structural and sustainable potential of culture needs to be used, so that cohesion in diversity can succeed" (Bundesregierung 2021, p. 65). Now, in contradiction, there is a clear focus on the recognition of diversity, whereas the specification of a national-cultural canon of binding values is not included in this official document.

All in all, the Leitkultur concept does not seem to be suitable for designing a functional model of democratic collective identity between a too-vague constitutional patriotism and a too-rigid national identity based on ethnocultural continuity. The concept of Leitkultur therefore remains, even in a merely symbolic interpretation, an instrument of conservative to right-wing actors and their attempts to preserve exclusive access to the narrative of a static historical continuity and one-sided affirmative access to the collective. That is the case when the right-wing populist party AfD calls for a German Leitkultur instead of "multiculturalism" in the election program for the 2021 Bundestag elections (Alternative für Deutschland 2021, p. 158). Following the idea of Leitkultur as the common predominant culture within a society, collective identity then is mainly constructed via traditional codes, thus cultural assimilation is required, and integration is ambitious and tends to be exclusive. Still, an exclusion from the outset based on primordial normative codes is not given from the outset, although numerous "authoritarian temptations" (Heitmeyer 2018) go hand in hand with it. However, a universalist integration throughout the recognition of basic political values such as the rule of law, political equality, freedom of speech, mutual tolerance, and religious and cultural neutrality is seen as insufficient for creating a social tie between the members of society.

\section{Conclusion: Democratic Identity as Discursive Reconstruction of Similarity and Differences}

Even though the Leitkultur debate began more than 20 years ago, the importance of such a debate has not diminished (Rohgalf 2016). If democracy wants to form a functional common identity, there must be open discourse and a consensual process of identity formation. Debates like the one on opportunities and risks of a Leitkultur can serve as a starting point (Bein 2020b). Hence, the crucial question for liberal

\footnotetext{
13 The term Leitkultur was adopted into the official government program of the CDU/CSU for the election term 2017-2021. There it is written: "Like every country, Germany needs a common bond: our Leitkultur, the culture that defines us as a nation. [...] It is in the mutual interest that integration takes place and succeeds. In this way we will prevent the emergence of parallel societies and multi-culturalism. [...] The German language is a particularly important part of our identity and guiding culture. We want to promote and appreciate it even more in the future [...]. Equality between men and women applies to all people living here, no matter where they come from. [...] Our history, with all its ups and downs, is our shared, unmistakable heritage. We want to convey it to everyone [...]. Our dialects, traditions and customs, as different from region to region, give Germany a friendly face and the continuity of tradition" (CDU Deutschland 2017, pp. 70-72).
} 
democracies is how they can create a strong collective identity in the sense of a political community, while recognizing individual and cultural pluralism. Having analyzed the debate on political integration models in Germany and its requirements for democratic collective identity, it becomes clear that a static definition of a German Leitkultur would in the long run neither achieve functional inclusion nor be able to generate sufficient cohesion for a political community due to exclusionist tendencies.

Therefore, the idea of a German Leitkultur, as well as any other concept of collective identity in democratic societies, must be controversial empirically and thus be interpreted within a pluralistic theoretical approach. Even though debates on political integration and related citizenship policies will surely always be influenced by political opportunity structures in the short term (Gerdes and Faist 2006), the longterm basis must be an open and functional democratic collective identity that deessentializes, or rather democratizes, conflicts regarding cultural and social identities. The solution to the Leitkultur debate in a plural democracy that wants to establish a strong, nonethnic cohesion is a balanced identity model with both inclusive and exclusive elements in all three dimensions of collective identity.

Putting too strong an emphasis on cultural differences will lead democratic societies and their political practice of consensus and compromise into a dead end (Jullien 2017). An exit from this impasse of essentializing cultural differences and different collective identities is only possible within a discursive framework that makes aware these differences as constructed and, hence, able to be reconstructed. Accordingly, for a functional model of democratic identity, the construction of the second dimension of identity, historical continuity, is crucial: The narrative about shared identity in time must not be static, but, as Hall (2018, pp. 181-182) puts it, must be able to constantly rebalance similarities and differences. In liberal democracies, the connection of individuals to identity groups is a central component of interest aggregation and articulation (Schubert and Schwiertz 2021). Put in concrete terms, "identity groups allow individuals to express themselves in democratic politics" (Gutmann 2003, p. 211). Since a complete exclusion of identity collectives and their interests runs counter to the notion of a functional democracy, the democratic process must be fundamentally open to any claims of recognition, as long as such are not accompanied by a violation of fundamental and human rights. However, it is just as little in the sense of the universal principle of democratic equality and justice to exclude from the outset an equal discourse about what is common or to reinterpret it as a one-sided adaptation process on the basis of fixed standards and majority cultures. This became clear in the court ruling on the Leitkultur concept, implemented in the Bavarian Integration Act: A one-sided commitment of public media reporting to Leitkultur ideals was ruled unconstitutional; rather, an intercultural educational approach, which at the same time does not disregard the search for the unifying element, would be recommended in the sense of a functional cultivation of identity.

Similar to Sebaldt's (2015) argumentation, it can finally be summed up that only the empirical analysis of de facto practices of political integration and identity configuration can show what actually constitutes functionally dosed tolerance and a consensual identity-making process. In its present form, however, the Leitkultur concept does not seem to be suitable for this purpose, since there is a too-excessive 
connection to historical continuities of the majority culture, which stands in the way of political universalism and thus also impedes a reciprocal process of positive affirmation between different parts of society. With reference to Stuart Hall (2018), the indispensable demand can be formulated that a democratic collective identity must be open toward discursive readjustment and negotiation of commonalities and differences.

Funding Open Access funding enabled and organized by Projekt DEAL.

Open Access This article is licensed under a Creative Commons Attribution 4.0 International License, which permits use, sharing, adaptation, distribution and reproduction in any medium or format, as long as you give appropriate credit to the original author(s) and the source, provide a link to the Creative Commons licence, and indicate if changes were made. The images or other third party material in this article are included in the article's Creative Commons licence, unless indicated otherwise in a credit line to the material. If material is not included in the article's Creative Commons licence and your intended use is not permitted by statutory regulation or exceeds the permitted use, you will need to obtain permission directly from the copyright holder. To view a copy of this licence, visit http://creativecommons.org/licenses/by/4. $0 /$.

Conflict of interest S. Bein declares that he has no competing interests.

\section{References}

Ahrens, Jörg. 2021. The enigma of origin: the notion of Leitkultur as a contemporary paradigm of Heimat. The Germanic Review 96(3):313-330.

Alternative für Deutschland, 2021. Deutschland, aber normal. Wahlprogramm zur Bundestagswahl 2021. https://www.afd.de/wahlprogramm/. Accessed 22 Dec 2021.

Amthor, Philipp. 2020. In guter Verfassung? Unser Land braucht eine Leitkultur-Debatte. In Eine Politik für morgen: Die junge Generation fordert ihr politisches Recht, ed. Mark Hauptmann, Ralph Brinkhaus, 19-30. Freiburg im Breisgau: Herder.

Anderson, Benedict. 2006. Imagined communities: reflections on the origin and spread of nationalism. London: Verso.

Assmann, Jan. 2000. Das kulturelle Gedächtnis: Schrift, Erinnerung und politische Identität in frühen Hochkulturen, 3rd edn., München: Beck.

Bayerische Staatskanzlei. 2016. Bayerisches Integrationsgesetz (BayInt). https://www.gesetze-bayern.de/ Content/Document/BayIntG-6. Accessed 7 Oct 2021.

Bayerischer Verfassungsgerichtshof. 2019. Einzelne Vorschriften des Bayerischen Integrationsgesetzes verfassungswidrig. https://www.bayern.verfassungsgerichtshof.de/media/images/bayverfgh/6-viii17u.a.-pressemitt.-entscheidung.pdf. Accessed 7 Oct 2021

Bein, Simon. 2020a. Pathologische Potenziale kultureller Identitäten: Eine Gefährdung der Demokratie? In Gibt es eine kulturelle Identität?, ed. Yves Bizeul, Dennis B. Rudolf, 151-176. Baden-Baden: Nomos.

Bein, Simon. 2020b. Anomie durch Identitätsgefährdung? Chancen und Risiken der Leitkulturkontroverse in Deutschland. In Demokratie und Anomie, ed. Martin Sebaldt, et al., 227-254. Wiesbaden: Springer VS.

Benhabib, Seyla. 1998. Democracy and identity: In the search of the civic polity. Philosophy \& Social Criticism 24(2-3):85-100.

Bergem, Wolfgang. 2019. 'Identität' in politischer Kultur, Demokratietheorie und der Identitären Bewegung. In Politische Kulturforschung reloaded, ed. Wolfgang Bergem, Paula Diehl, and Hans J. Lietzmann, 249-273. Bielefeld: transcript.

Bizeul, Yves. 2004. Kulturalistische, republikanische und zivilgesellschaftliche Konzepte für die Integration von Immigranten. In Integration von Migranten, ed. Yves Bizeul, 137-175. Wiesbaden: Deutscher Universitätsverlag.

Brubaker, Rogers. 2001. The return of assimilation? Changing perspectives on immigration and its sequels in France, Germany, and the United States. Ethnic and Racial Studies 24(4):531-548. 
Bundesregierung. 2020. Nationaler Aktionsplan Integration. https://www.nationaler-aktionsplan-integration. de/napi-de/aktionsplan. Accessed 7 Oct 2021.

Bundesregierung. 2021. Nationaler Aktionsplan Integration. Bericht Phase IV: Zusammenwachsen: Vielfalt gestalten - Einheit sichern. https:/www.nationaler-aktionsplan-integration.de/napi-de/ aktionsplan. Accessed 7 Oct 2021.

CDU Deutschland. 2017. Für ein Deutschland, in dem wir gut und gerne leben: Regierungsprogramm 2017-2021. https://www.cdu.de/system/tdf/media/dokumente/170703regierungsprogramm2017.pdf. Accessed 3 Mar 2021.

Citrin, Jack, and David O. Sears. 2009. Balancing national and ethnic identities: the psychology of E pluribus unum. In Measuring identity, ed. Rawi Abdelal, et al., 145-174. Cambridge: Cambridge University Press.

Cronin, Ciaran. 2003. Democracy and collective identity: in defence of constitutional patriotism. European Journal of Philosophy 11(1):1-28.

Eisenstadt, Shmuel N. 1991. Die Konstruktion nationaler Identitäten in vergleichender Perspektive. In Nationale und kulturelle Identität, ed. Bernhard Giesen, 21-38. Frankfurt am Main: Suhrkamp.

Francis, Emerich. 1965. Ethnos und Demos. Berlin: Duncker \& Humblot.

Fukuyama, Francis. 2006. Identity, immigration, and liberal democracy. Journal of Democracy 17(2):5-20.

Fukuyama, Francis. 2018a. Why national identity matters. Journal of Democracy 29(4):5-15.

Fukuyama, Francis. 2018b. Identity. The demand for dignity and the politics of resentment. New York: Farrar, Straus and Giroux.

Fulbrook, Mary. 1999. German national identity after the holocaust. Cambridge: Polity Press.

Garcia, Tristan. 2018. Wir. Berlin: Suhrkamp.

Gauck, Joachim. 2017. What should our country be like? https://www.bundespraesident.de/SharedDocs/ Reden/EN/JoachimGauck/Reden/2017/170118-What-should-our-country-be-like.html. Accessed 5 Mar 2021.

Gellner, Ernest. 1983. Nations and nationalism. Ithaca: Cornell University Press.

Gerdes, Jürgen, and Thomas Faist. 2006. Von ethnischer zu republikanischer Integration. Berliner Journal für Soziologie 3:133-335.

Göhler, Gerhard. 2003. Leitkultur als symbolische Integration. Überlegungen zum Gebrauch eines umstrittenen Konzepts. In Kunst, Macht und Institution, ed. Joachim Fischer, Hans Joas, 304-315. Frankfurt, New York: Campus.

Gutmann, Amy. 2003. Identity in democracy. Princeton: Princeton University Press.

Habermas, Jürgen. 1993. Anerkennungskämpfe im demokratischen Rechtsstaat. In Multikulturalismus und die Politik der Anerkennung, ed. Charles Taylor, Amy Gutmann, and Jürgen Habermas, 147-196. Frankfurt am Main: Fischer.

Habermas, Jürgen. 1994. Faktizität und Geltung. Beiträge zur Diskurstheorie des Rechts und des demokratischen Rechtsstaats, 4th edn., Frankfurt am Main: Suhrkamp.

Habermas, Jürgen. 2006. Vorpolitische Grundlagen des demokratischen Rechtsstaates. In Dialektik der Säkularisierung, 5th edn., ed. Jürgen Habermas, Joseph Ratzinger, 15-37. Freiburg im Breisgau: Herder.

Hall, Stuart. 1994. Rassismus und kulturelle Identität. Hamburg: Argument.

Hall, Stuart. 2018. Das verhängnisvolle Dreieck. Rasse, Ethnie, Nation. Berlin: Suhrkamp.

Häusler, Alexander. 2002. Multikulturalismus als Bedrohung deutscher Identität. In Themen der Rechten - Themen der Mitte, ed. Christoph Butterwegge, et al., 67-91. Opladen: Leske + Budrich.

Heinhold, Hubert. 2018. Das Bayerische Integrationsgesetz und die Leitkultur. In Hohenheimer Horizonte. Festschrift für Klaus Barwig, ed. Stephan Beichel-Benedetti, Constanze Janda, 193-210. BadenBaden: Nomos.

Heitmeyer, Wilhelm. 2018. Autoritäre Versuchungen. Berlin: Suhrkamp.

Hentges, Gudrun. 2002. Das Plädoyer für eine ,deutsche Leitkultur ' - Steilvorlage für die extreme Rechte? In Themen der Rechten - Themen der Mitte, ed. Christoph Butterwegge, et al., 95-122. Opladen: Leske + Budrich.

Hess, Christin, and Simon Green. 2016. Introduction: the changing politics and policies of migration in Germany. German Politics 25(3):315-328.

Hidalgo, Oliver. 2020. Kritik der Identitätspolitik in der Demokratie. Ethik und Gesellschaft https://doi. org/10.18156/eug-1-2020-art-6.

Isin, Engin F., and Bryan S. Turner. 2007. Investigating citizenship: an agenda for citizenship studies. Citizenship Studies 11(1):5-17.

Isin, Engin F., and Patrizia Wood. 1999. Citizenship and identity. London: SAGE. 
Jahn, Egbert. 2012. 'Multikulturalismus' oder deutsche ,Leitkultur' als Maximen der ,Integration“ von Ausländern. In Politische Streitfragen, ed. Egbert Jahn, 58-75. Wiesbaden: Springer VS.

Jullien, Francois. 2017. Es gibt keine kulturelle Identität. Berlin: Suhrkamp.

Koopmans, Ruud, Ines Michalowski, and Stine Waibel. 2012. Citizenship rights for immigrants: national political processes and cross-national convergence in western Europe, 1980-2008. American Journal of Sociology 117(4):1202-1245.

Kymlicka, Will. 1995. Multicultural citizenship. A liberal theory of minority rights. Oxford: Clarendon Press.

Lammert, Norbert. 2017. Verfassungspatriotismus greift zu kurz. https://www.cicero.de/innenpolitik/ debatte-um-leitkultur-verfassungspatriotismus-greift-zu-kurz (Created 4 May 2017). Accessed 5 Mar 2021.

Landwehr, Claudia, and Nils D. Steiner. 2017. Where democrats disagree: citizens' normative conceptions of democracy. Political Studies 65(4):786-804.

Lilla, Mark. 2016. The end of identity liberalism. www.nytimes.com/2016/11/20/opinion/sunday/the-endof-identity-liberalism.html (Created 20 Nov 2016). Accessed 5 Mar 2021.

de Maizière, Thomas. 2017. Wir sind nicht Burka: Leitkultur für Deutschland, was ist das eigentlich? https://www.bild.de/politik/inland/thomas-de-maiziere/leitkultur-fuer-deutschland-51509022.bild. html (Created 29 Apr 2017). Accessed 3 July 2019.

Manz, Stefan. 2004. Constructing a normative national identity: the Leitkultur debate in Germany, 2000/2001. Journal of Multilingual and Multicultural Development 25(5-6):481-496.

Meier-Walser, Reinhard. 2017. Die Diskussion um eine Leitkultur. Hintergrund, Positionen und aktueller Stand. München: Hanns-Seidel-Stiftung.

Merkel, Wolfgang, and Michael Zürn. 2019. The defects of cosmopolitan and communitarian democracy. In The Struggle Over Borders, ed. Peter de Wilde, et al., 207-237. Cambridge: Cambridge University Press.

Merz, Friedrich. 2000. Einwanderung und Identität. https://www.welt.de/print-welt/article540438/Einwan derung-und-Identitaet.html (Created 25 Oct 2000). Accessed 5 Mar 2021.

Moran, Anthony. 2011. Multiculturalism as nation-building in Australia: Inclusive national identity and the embrace of diversity. Ethnic and Racial Studies 34(12):2153-2172.

Mounk, Yascha. 2019. Der Zerfall der Demokratie: Wie der Populismus den Rechtsstaat bedroht. München: Droemer.

Mouritsen, Per. 2013. The resilience of citizenship traditions: Civic integration in Germany, Great Britain and Denmark. Ethnicities 13(1):86-109.

Mouritsen, Per, Daniel Faas, Nasar Meer, and Nynke de Witte. 2019. Leitkultur debates as civic integration in North-Western Europe: The nationalism of 'values' and 'good citizenship'. Ethnicities 19(4):632-653.

Müller, Jan-Werner. 2007. Is europe converging on constitutional patriotism? (And if so: is it justified?). Critical Review of International Social and Political Philosophy 10(3):377-387.

Müller, Jan-Werner. 2010. Verfassungspatriotismus. Berlin: Suhrkamp.

Münkler, Herfried, and Marina Münkler. 2016. Die neuen Deutschen: Ein Land vor seiner Zukunft, 2nd edn., Berlin: Rowohlt.

Oberndörfer, Dieter. 2001. Leitkultur und Berliner Republik. Die Hausordnung der multikulturellen Gesellschaft Deutschlands ist das Grundgesetz. Aus Politik und Zeitgeschichte 2001(1-2):27-30.

Ohlert, Martin. 2015. Zwischen „Multikulturalismus “ und „Leitkultur“. Wiesbaden: Springer VS.

Özoguz, Aydan. 2017. "Leitkultur verkommt zum Klischee des Deutschseins." Der Tagesspiegel, May 14th 2017.

Palmowski, Jan. 2008. In search of the German nation: citizenship and the challenge of integration. Citizenship Studies 12(6):547-563.

Parsons, Talcott. 2003. Das System moderner Gesellschaften. Weinheim and München: Juventa.

Pautz, Hartwig. 2005. The politics of identity in Germany: the Leitkultur debate. Race \& Class 46(4):39-52.

Pickel, Gert, and Susanne Pickel. 2018. Migration als Gefahr für die politische Kultur? Kollektive Identitäten und Religionszugehörigkeit als Herausforderung demokratischer Gemeinschaften. Zeitschrift für Vergleichende Politikwissenschaft 12(1):297-320.

Piwoni, Eunike. 2012. Nationale Identität im Wandel. Deutscher Intellektuellendiskurs zwischen Tradition und Weltkultur. Wiesbaden: Springer VS.

Rawls, John. 2003. Politischer Liberalismus. Frankfurt am Main: Suhrkamp.

Reckwitz, Andreas. 2017. Die Gesellschaft der Singularitäten. Berlin: Suhrkamp. 
Riedel, Sabine. 2018. Streit um nationale Identitäten. Zeitschrift für Vergleichende Politikwissenschaft 28(2):217-223.

Rohgalf, Jan. 2016. Kollektive Identität als Mauer: Versuch über die Leitkultur. In Menschen, Macht und Mauern, ed. Ludmila Lutz-Auras, Pierre Gottschlich, 277-298. Wiesbaden: Springer VS.

Schönwälder, Karen, and Triadafilos Triadafilopoulos. 2016. The new Differentialism: responses to immigrant diversity in Germany. German Politics 25(3):366-380.

Schubert, Karsten, and Helge Schwiertz. 2021. Konstruktivistische Identitätspolitik. Zeitschrift für Politikwissenschaft Online First. https://doi.org/10.1007/s41358-021-00291-2.

Sebaldt, Martin. 2015. Pathologie der Demokratie. Wiesbaden: Springer VS.

Siri, Jasmin, and Marcel Lewandowsky. 2019. 'Wir sind das Volk'. In Politische Kulturforschung reloaded, ed. Wolfgang Bergem, Paula Diehl, and Hans J. Lietzmann, 274-294. Bielefeld: transcript.

Smith, Anthony D. 2000. The 'sacred' dimension of nationalism. Millenium 29(3):791-814.

Stein, Tine. 2008. Gibt es eine multikulturelle Leitkultur als Verfassungspatriotismus? Leviathan 36(1):33-53.

Steinbrück, Peer. 2018. „Über Zivilität und Umgangsformen.“ Die Zeit, March 1st 2018, p. 6.

Sternberger, Dolf. 1990. Verfassungspatriotismus. Frankfurt am Main: Insel.

Straub, Jürgen. 2018. Multiple Identitäten in modernen Gesellschaften. Zeitschrift für Politikwissenschaft 28(2):205-216.

Taylor, Charles. 2002. Wieviel Gemeinschaft braucht die Demokratie? Frankfurt am Main: Suhrkamp.

Tibi, Bassam. 2001. Leitkultur als Wertekonsens: Bilanz einer missglückten deutschen Debatte. Aus Politik und Zeitgeschichte 2001(1-2):23-26.

Tibi, Bassam. 2002. Europa ohne Identität? Leitkultur oder Wertebeliebigkeit, 3rd edn., Berlin: Siedler.

Tibi, Bassam. 2017. "Eine neurotische Nation.” Der Tagesspiegel, July 16.

Tibi, Bassam. 2018. Islamische Zuwanderung und ihre Folgen: Der neue Antisemitismus, Sicherheit und die „neuen Deutschen“. Stuttgart: ibidem.

de Tocqueville, Alexis. 1985. Über die Demokratie in Amerika. Stuttgart: Reclam.

Vorländer, Hans. 2013. Demokratie und Transzendenz. In Demokratie und Transzendenz, ed. Hans Vorländer, 11-37. Bielefeld: transcript.

Weber, Max. 1964. Wirtschaft und Gesellschaft: Grundriß der verstehenden Soziologie. Köln: Kiepenheuer \& Witsch.

Wittlinger, Ruth. 2010. German national identity in the twenty-first century. Basingstoke: Palgrave.

Young, Iris M. 2000. Inclusion and democracy. Oxford: Oxford University Press. 